\title{
STUDENTS' ACHIEVEMENT ON INSTITUTIONAL TOEFL AN EVALUATION AT FBS UNIVERSITAS WIJAYA PUTRA
}

\author{
${ }^{* 1}$ Arjunani, ${ }^{\# 2}$ Yeni Probowati, ${ }^{* 3}$ Yulis Setyowati, ${ }^{* 4}$ Deni Kuswahono
}

\begin{abstract}
${ }^{* 1}$ EnglishLlecturer, Language and Literature Faculty, Universitas Wijaya Putra, Indonesia
${ }^{\# 2}$ EnglishLlecturer, Language and Literature Faculty, Universitas Wijaya Putra, Indonesia

${ }^{*}$ EnglishLlecturer, Language and Literature Faculty, Universitas Wijaya Putra, Indonesia

${ }^{* 4}$ EnglishLlecturer, Language and Literature Faculty, Universitas Wijaya Putra, Indonesia
\end{abstract}

Corresponding Author Email: yeniprobowati@uwp.ac.id

\section{A B S T R A C T S}

This study tries to describe students' achievement on institutional TOEFL in Universitas Wijaya Putra. The test is meant as a means of evaluation upon the launching of a mandatory subject as a prerequisite towards final paper writing. The program begins with ten weeks of test preparation completed with a try-out test and the final test. This is a descriptive study since it tries to depict the result of their achievement and the most difficult section of the test. The data analysis uses the computation upon the results mostly applied for Excel Program, particularly in finding the Mean (X) and the Standard Deviation (S). The findings derived from the data analysis tell that $62.85 \%$ of the class belong to Grade D which means it is far below expectation. The finding also identified that Listening Section is to be the most difficult part of the test. Still, the findings say none of the students included into the level of either extremely excellent or failed. It is a big task to fulfill a better target for the coming classes by undergoing revision and development in many aspects, especially in time allocation and the module.

\begin{tabular}{l}
\hline A R T I C L E I N F O \\
\hline Article History: \\
Received: May, 2021
\end{tabular}

Revised: May, 2021

Published: June, 2021

\section{Keywords:}

Students' Achievement, Institutional TOEFL, Evaluation,

How to cite: Arjunani, A., Probowati, Y., Setyowati, Y., \& Kuswahono, D. (2021). Students' Achievement on Institutional TOEFL an Evaluation at FBS Universitas Wijaya Putra. Jo-ELT (Journal of English Language Teaching) Fakultas Pendidikan Bahasa \& Seni Prodi Pendidikan Bahasa Inggris IKIP, 8(1), 83-93. doi:https://doi.org/10.33394/jo-elt.v8i1.3841

\section{INTRODUCTION}

It should be realized that every single thing people do is based on the cycle of planning, organizing, actualizing, and controlling (management). In fact, it just a matter of time span they need to do it: meaning, sometimes human beings have enough time to prepare all the steps, yet mostly they do it spontaneously. However, official work does need well prepared. In academic work, teaching-learning activities particularly, the lecturers also have to follow the cycle of management properly in terms of planning for the coming schedule of each semester; organizing the right lectures on their expertise; Actualizing the instructions as scheduled in classroom practice: controlling the whole three chains into an assessment through periodic evaluation such as Mid-semester Test and Final-semester Test.

In reality, teaching-learning activities as a whole including the administering of a test must be well planned in order to get feedback on varied aspects of the instructions that have been completed in a period of time. The feedback may identify how far the objectives of 
instructions are achieved; whether the materials are properly selected; whether the methods used are applicable and acceptable by the students, whether the right lecturer on the right subject, and further information can be depicted from a test result.

In fact, administering a test as controlling is the most point to be highlighted since it can tell lots of things when it wants to see beyond the lines. Generally, the result of a test may tell the performance of both lectures and students along the semester as the Mean of the scores indicates how well the students were able to absorb and comprehend the subject matter their Lecture gave. Each student can see his position among the peers to they should know how to upgrade himself to the achievement expected. While for the lecture, he is expected to diagnose through his test-item analysis to identify which part of the previous instructions are least comprehended and need remedial instruction.

As controlling that important, the writer is intended to give a closed look and study on the utmost final assessment that the Fakultas Bahasa dan Sastra of Universitas Wijaya Putra Surabaya hold as a requirement for those students who have completed their Final-paper writing (thesis). The assessment is named under institutional TOEFL which is internally used only, yet not customized since faculty does always up-date TOEFL (PBT) collection from which FBS has one complete test sample to save, meaning it is not used as classroom material; instead saved the set as the item-test bank. The institutional TOEFL is completed with the writing and speaking section, so all in all there will be 5 sections including listening, structure, and written expressions, as well as reading comprehension. The last three sections will apply the standardized scoring system of real TOEFL in line with the set taken from it. However, the speaking and writing sections which generally received little attention (Underhill, 1987: 3) will apply the FSI (Foreign Service Institute) in scoring them. the result of this study is expected to give the real-solid official information upon the holistic performance of lectures as big teamwork and to generally tell academic achievement upon the target of language learning that comprised of four language skills (listening, speaking, reading, writing) and three language components (vocabulary, pronunciation, grammar).

Language Teaching is generally the same as other instructional activities. The only difference lays in whether the language teaching is about the mother-tongue / local, national language, or other-country language known as a foreign language. The fact is, even teaching other-country language can be considered as a second language or completely as a foreign language. For example, the English Teaching in Malaysia more to TESL (Teaching English as Second Language), while the English Teaching in Indonesia tends to be TEFL (Teaching English as Foreign Language) (Rivers, 1985).

Teaching English as a foreign language includes both knowing about the language (the usage), meaning to communicate using the target language. Thus, the teaching process should properly apply the 3 P: Present, Practice, and Produce. The teacher is expected to introduce the language properly as vocabulary cannot be separated from pronunciation since a slightly different pronunciation may completely change the meaning of a word. Even the use of grammar correctly is needed, for it may indicate the difference between active sentence construction and passive one. Djiwandono (2008) says penyelenggaraan pengajaran yang utuh secara keseluruhan bahkan meliputi pula penyelenggaraan tes untuk memperoleh berbagai macam dan bentuk umpan balik tentang pengajaran yang telah diselenggarakan. Meaning that the teaching-learning process as a whole includes the administering test with the intention of getting feedback in various types and kinds from the given instruction. 
Constructing a test should be related to the target of language learning to consider it valid. In fact, language should be taught integrated comprising the language skills and language components. In practice, the lecturer tends to focus on giving the language components (vocabulary, pronunciation, Grammar) as discrete subjects with the expectation of broad knowledge and a huge reservoir to have strong basic support to perform the language skills (listening, speaking, reading, writing). The attitude towards the target of language learning inspired the administering of the institution test of English as a Foreign Language as an internal assessment hold for the final-semester students at FBS of Universitas Wijaya Putra Surabaya. It is confirmed that the sections of listening, structure, and written expressions, as well as reading comprehension, are assessed using the standard TOEFL system. the speaking section will apply the holistic rating scale that has 7 bands (Sohamy, 1985: 179) while the writing section will use the rating scale for evaluating holistic written language that bears 5 bands (Shohamy, 1985: 197). The application of that two holistic assessments is in accordance with the impromptu task an examinee has to do within a time limit; in order words, spontaneity is far from perfection, yet an examiner is still to hold the assessment officially by using a legal measurement.

As teaching adult learners at the university level is more field-specific oriented, the test for Speaking can be constructed which are designed to assess the testability to communicate in relation to typical language the target genres (Brown, 2004). In assessing speaking the examiner may use elicitation as it is the process of drawing out something, of provoking a response.

\section{RESEARCH METHOD}

\section{Research Design}

According to Ary, Jacob \& Razavieh (1972), descriptive studies are designed to obtain information concerning the current status of the phenomenon and are directed toward determining the nature of the situation as it exists at the time of the study. In line with the statement above, as this study is a case study, the writers decided to use descriptive studies as the research design. In a sense, descriptive studies are merely the accumulation of basic data that have nothing to do with seeking and explaining any correlation, testing hypothesis, establishing prediction, even finding implications.

The current study tries to find out the achievement of the final-semester students at FBS-UWP Surabaya toward institutional TOEFL in terms of all sections (listening; structure and written expression; reading comprehension; writing; and speaking). This descriptive method is considered appropriate since it is intended to describe what exists at the time of the study. For this purpose, the most needed is a quantitative design to determine the percentage of the achievers of each section. In the end, every outcome will be described in terms of determining criteria.

\section{Population and sample}

The test-taker for the institutional TOEFL is the students of FBS Universitas Wijaya Putra Surabaya, the writer determine to include all of them (35 students) as the respondents. Thus, this study will not need sampling.

\section{Data Analysis}

The data of this study is collected from the scores of the institutional TOEFL in every section. It is credible as it is stated that a test is a means of measuring the knowledge, skills, feeling, intelligence, or aptitude of individuals or groups (Gay, 1987: 127). 
The data of this study is collected after the scoring of the test that was held in May 2017 took place in Kampus-1 Universitas Wijaya Putra, started from 10 a.m up to 2 p.m. The test lasted from 10 to 12 a.m followed by a lunch break, then began with the Writing section for 35 minutes, ended with the speaking section.

Data will be analyzed by section. After the scores were listed from the highest to the lowest, the researcher can find out the Mean and the Standard Deviation by using the Excell system in the computer. Using the Mean (X) and Standard Deviation (S) we may find out the spreading of the scores for grading the students, how many of them belong to normal achievers between $(X-1 S)-(X+1 S)$ means score $C$; above normal achievers between $(X-1 S)$ $(\mathrm{X}-2 \mathrm{~S})$ means D, while $<(\mathrm{X}-2 \mathrm{~S})$ means E. From the percentage of the achievers by section we can identify how well the subjects go along complete academic years ( 8 semester or 4 years). Then, the program or even a department evaluation may take place as well.

\section{RESEARCH FINDINGS AND DISCUSSION Research Findings}

There are a total of 35 test-takers, three of them are alumnus from varied academic-year who are interested in joining the institutional TOEFL then. However, they will not be included as the population of the research since this study is meant to evaluate the current achievement of the students in the same academic year. Thus, the respondents of the study consist of 35 test-takers with detailed scores in table 1. 
Table 1

TOEFL Score Data of FBS Universitas Wijaya Putra

\begin{tabular}{|c|c|c|c|c|c|c|c|}
\hline No & Respondent & NPM & Listening & Reading & Structure & $\begin{array}{l}\text { Total } \\
\text { Score }\end{array}$ & $\begin{array}{c}\text { Toefl } \\
\text { Equivalent }\end{array}$ \\
\hline 1. & PNA & 12181007 & 42 & 44 & 44 & 130 & 433 \\
\hline 2. & $\mathrm{AR}$ & 12181020 & 41 & 42 & 36 & 119 & 397 \\
\hline 3. & $\mathrm{NH}$ & 12181027 & 47 & 51 & 37 & 135 & 450 \\
\hline 4. & $\mathrm{BI}$ & 13181002 & 46 & 44 & 35 & 125 & 417 \\
\hline 5. & PF & 13181004 & 49 & 54 & 43 & 146 & 487 \\
\hline 6. & DPS & 13181005 & 48 & 55 & 42 & 145 & 483 \\
\hline 7. & $\mathrm{~K}$ & 13181006 & 47 & 52 & 36 & 135 & 450 \\
\hline 8. & $\mathrm{KN}$ & 13181007 & 41 & 44 & 41 & 126 & 420 \\
\hline 9. & MSI & 13181008 & 41 & 53 & 39 & 133 & 443 \\
\hline 10. & $\mathrm{SH}$ & 13181009 & 44 & 43 & 35 & 122 & 407 \\
\hline 11. & LHIM & 13181013 & 38 & 43 & 43 & 124 & 413 \\
\hline 12. & $\mathrm{NH}$ & 13181014 & 41 & 51 & 32 & 124 & 413 \\
\hline 13. & EMS & 13181015 & 59 & 63 & 54 & 176 & 587 \\
\hline 14. & $\mathrm{RS}$ & 13181016 & 45 & 57 & 48 & 150 & 500 \\
\hline 15. & UP & 13181017 & 41 & 50 & 29 & 120 & 400 \\
\hline 16. & NNI & 13181018 & 45 & 55 & 29 & 129 & 430 \\
\hline 17. & AP & 13181021 & 44 & 45 & 35 & 124 & 413 \\
\hline 18. & ITUN & 13181024 & 45 & 52 & 39 & 136 & 453 \\
\hline 19. & MFN & 13181026 & 45 & 46 & 35 & 126 & 420 \\
\hline 20. & YP & 13181027 & 41 & 45 & 38 & 124 & 413 \\
\hline 21. & IIM & 13181028 & 45 & 54 & 32 & 131 & 437 \\
\hline 22. & VND & 13181029 & 51 & 51 & 44 & 146 & 487 \\
\hline 23. & SA & 13181030 & 32 & 50 & 28 & 110 & 367 \\
\hline 24. & $\mathrm{OKC}$ & 13181031 & 43 & 41 & 37 & 121 & 403 \\
\hline 25. & RSW & 13181032 & 42 & 54 & 34 & 130 & 433 \\
\hline 26. & SAZ & 13181033 & 54 & 60 & 54 & 168 & 560 \\
\hline 27. & APPS & 13181034 & 35 & 42 & 28 & 105 & 350 \\
\hline 28. & TF & 13181035 & 48 & 60 & 47 & 155 & 517 \\
\hline 29. & RIS & 13181038 & 51 & 51 & 41 & 143 & 477 \\
\hline 30. & SK & 13181040 & 44 & 51 & 34 & 129 & 430 \\
\hline 31. & DARP & 13181047 & 41 & 56 & 46 & 143 & 477 \\
\hline 32. & DP & 15071028 & 51 & 56 & 39 & 146 & 487 \\
\hline 33. & AEN & 15071033 & 41 & 45 & 46 & 132 & 440 \\
\hline 34. & FDH & 16071026 & 41 & 48 & 34 & 123 & 410 \\
\hline 35. & $\mathrm{AF}$ & 13181041 & 31 & 42 & 29 & 102 & 340 \\
\hline
\end{tabular}

In the process of analyzing the data, the researcher grades the respondent's score from the highest to the lowest, in addition, the researcher also includes the Mean score (X) and Standard Deviation (S). 
Table 2

Score Analysis of the Listening Section

\begin{tabular}{|c|c|c|c|c|c|}
\hline No & Respondent & $\begin{array}{l}\text { Listening } \\
\text { Score }\end{array}$ & No & Respondent & $\begin{array}{c}\text { Listening } \\
\text { Score }\end{array}$ \\
\hline 1. & EMS & 59 & 19. & SK & 44 \\
\hline 2. & SAZ & 54 & 20. & $\mathrm{OKC}$ & 43 \\
\hline 3. & VND & 51 & 21. & PNA & 42 \\
\hline 4. & RIS & 51 & 22. & RSW & 42 \\
\hline 5. & DP & 51 & 23. & AR & 41 \\
\hline 6. & PF & 49 & 24. & $\mathrm{KN}$ & 41 \\
\hline 7. & DPS & 48 & 25 . & MSI & 41 \\
\hline 8. & $\mathrm{TF}$ & 48 & 26. & $\mathrm{NH}$ & 41 \\
\hline 9. & $\mathrm{NH}$ & 47 & 27. & UP & 41 \\
\hline 10. & K & 47 & 28. & YP & 41 \\
\hline 11. & BI & 46 & 29. & DARP & 41 \\
\hline 12. & $\mathrm{RS}$ & 45 & 30. & $\mathrm{AEN}$ & 41 \\
\hline 13. & NNI & 45 & 31. & $\mathrm{FDH}$ & 41 \\
\hline 14. & ITUN & 45 & 32. & LHIM & 38 \\
\hline 15. & MFN & 45 & 33. & APPS & 35 \\
\hline 16. & IIM & 45 & 34. & SA & 32 \\
\hline 17. & SH & 44 & 35. & $\mathrm{AF}$ & 31 \\
\hline 18. & $\mathrm{AP}$ & 44 & & & \\
\hline \multicolumn{6}{|c|}{ Mean $(X)=44$} \\
\hline & & andard Dev & S) & .625 & \\
\hline
\end{tabular}

In table 2 shows the results of the analysis upon the Listening Section upon the institutional TOEFL held by FBS-UWP Surabaya. The Mean score (X) of the listening section was 44 and the Standard Deviation (S) was 5.625. 
Table 3

Score Analysis of the Reading Section

\begin{tabular}{|c|c|c|c|c|c|}
\hline No & Respondents & $\begin{array}{c}\text { Reading } \\
\text { Scores }\end{array}$ & No & Respondents & $\begin{array}{c}\text { Reading } \\
\text { Scores }\end{array}$ \\
\hline 1. & EMS & 63 & 19. & SK & 51 \\
\hline 2. & SAZ & 60 & 20. & UP & 50 \\
\hline 3. & $\mathrm{TF}$ & 60 & 21. & SA & 50 \\
\hline 4. & $\mathrm{RS}$ & 57 & 22. & $\mathrm{FDH}$ & 48 \\
\hline 5. & DARP & 56 & 23. & MFN & 46 \\
\hline 6. & DP & 56 & 24. & AP & 45 \\
\hline 7. & DPS & 55 & 25 . & YP & 45 \\
\hline 8. & NNI & 55 & 26. & $\mathrm{AEN}$ & 45 \\
\hline 9. & $\mathrm{PF}$ & 54 & 27. & PNA & 44 \\
\hline 10. & IIM & 54 & 28. & BI & 44 \\
\hline 11. & RSW & 54 & 29. & $\mathrm{KN}$ & 44 \\
\hline 12. & MSI & 53 & 30. & SH & 43 \\
\hline 13. & $\mathrm{~K}$ & 52 & 31. & LHIM & 43 \\
\hline 14. & ITUN & 52 & 32. & AR & 42 \\
\hline 15. & $\mathrm{NH}$ & 51 & 33. & APPS & 42 \\
\hline 16. & $\mathrm{NH}$ & 51 & 34. & $\mathrm{AF}$ & 42 \\
\hline 17. & VND & 51 & 35. & $\mathrm{OKC}$ & 41 \\
\hline 18. & RIS & 51 & & & \\
\hline \multicolumn{6}{|c|}{ Mean $/(X)=50$} \\
\hline \multicolumn{6}{|c|}{ Standard Deviation $(S)=5.901$} \\
\hline
\end{tabular}

In table 3 shows the results of the analysis upon the Reading Section upon the institutional TOEFL held by FBS-UWP Surabaya. The Mean score (X) of the reading section was 50 and the Standard Deviation (S) was 5.901. 
Table 4

Score Analysis of the Structure and Written Expressions Section

\begin{tabular}{|c|c|c|c|c|c|}
\hline No & Respondents & $\begin{array}{c}\text { Structure and } \\
\text { Written } \\
\text { Expressions } \\
\text { Scores } \\
\end{array}$ & No & Respondents & $\begin{array}{c}\text { Structure and } \\
\text { Written } \\
\text { Expressions } \\
\text { Scores } \\
\end{array}$ \\
\hline 1. & EMS & 54 & 19. & $\mathrm{OKC}$ & 37 \\
\hline 2. & SAZ & 54 & 20. & AR & 36 \\
\hline 3. & $\mathrm{RS}$ & 48 & 21. & $\mathrm{~K}$ & 36 \\
\hline 4. & $\mathrm{TF}$ & 47 & 22. & BI & 35 \\
\hline 5. & DARP & 46 & 23. & $\mathrm{SH}$ & 35 \\
\hline 6. & AEN & 46 & 24. & AP & 35 \\
\hline 7. & PNA & 44 & 25. & MFN & 35 \\
\hline 8. & VND & 44 & 26. & RSW & 34 \\
\hline 9. & $\mathrm{PF}$ & 43 & 27. & SK & 34 \\
\hline 10. & LHIM & 43 & 28. & FDH & 34 \\
\hline 11. & DPS & 42 & 29. & $\mathrm{NH}$ & 32 \\
\hline 12. & $\mathrm{KN}$ & 41 & 30. & IIM & 32 \\
\hline 13. & RIS & 41 & 31. & UP & 29 \\
\hline 14. & MSI & 39 & 32. & NNI & 29 \\
\hline 15. & ITUN & 39 & 33. & $\mathrm{AF}$ & 29 \\
\hline 16. & DP & 39 & 34. & SA & 28 \\
\hline 17. & YP & 38 & 35. & APPS & 28 \\
\hline 18. & $\mathrm{NH}$ & 37 & & & \\
\hline \multicolumn{6}{|c|}{ Mean $/(X)=38.371$} \\
\hline & & Standard & (S) & & \\
\hline
\end{tabular}

In table 4 shows the results of the analysis upon the Reading Section upon the institutional TOEFL held by FBS-UWP Surabaya. The Mean score (X) of Structure and Written Expressions was 38.371 and the Standard Deviation (S) was 6.826. Moreover, it will measure their instructors' accomplishment upon the subject had been given to their students; at the same time-in macroscope can be functioned as the evaluation of the instructional program as a whole.

\section{Score Distribution of Listening Section}

Bearing the Mean of 44 and the Standard Deviation of 5.625, the score distribution of the listening section is described in figure 1. 


$\begin{array}{|ll|}X+1 S=44+5.625 & =49.625 \\ X+2 S=44+11.25 & =55.25 \\ X+3 S=44+16.875 & =60.875 \\ & \\ X-1 S=44-5.626 & =38.375 \\ X-2 S=44-11.25 & =32.75 \\ X-3 S=44-16.875 & =27.125\end{array}$

Figure 1. Score Distribution of the Listening Section

The computation based on the Score Distribution Formula tells that grade A ranges between scores $>60.88$, grade $\mathrm{B}$ ranges between scores 55.25 - 59.99, grade $\mathrm{C}$ ranges between scores 49.62 - 54.99, grade D ranges between scores 38.37 - 48.99, grade $\mathrm{E}$ ranges between scores 32.75 - 37.99, grade F ranges between scores $27.12-31.99$.

\section{Score Distribution of Reading Section}

Having the Mean of 50 and the Standard Deviation of 5.901, the score distribution of the reading section is described in figure 2 .

\begin{tabular}{|ll|}
\hline$X+1 S=50+5.901$ & $=55.901$ \\
$X+2 S=50+11.802$ & $=61.802$ \\
$X+3 S=50+17.703$ & $=67.703$ \\
$X-1 S=50-5.901$ & $=44.099$ \\
$X-2 S=50-11.802$ & $=38.198$ \\
$X-3 S=50-17.703$ & $=32.297$ \\
\hline
\end{tabular}

Figure 2. Score Distribution of the Reading Section

The computation based on the score distribution formula tells that grade A ranges between scores $>67.703$, grade $\mathrm{B}$ ranges between scores $6.802-66.999$, grade $\mathrm{C}$ ranges between scores 55.901 - 60.999, grade D ranges between scores 44.099 - 54.999, grade E ranges between scores 38.198 - 43.999, grade F ranges between scores 32.297 - 37.999.

\section{Scores Distribution of Structure and Written Expressions}

Bearing the Mean of 38.371 and the Standard Deviation of 5.076, the score distribution of the structure and written expression section is described in figure 3.

\begin{tabular}{|ll|}
\hline$X+1 S=38.371+5.076$ & $=43.447$ \\
$X+2 S=38.371+10.152$ & $=48.523$ \\
$X+3 S=38.371+15.228$ & $=53.599$ \\
& \\
$X-1 S=38.371-5.076$ & $=33.295$ \\
$X-2 S=38.371-10.152$ & $=28.219$ \\
$X-3 S=38.371-15.228$ & $=23.143$ \\
\hline
\end{tabular}

Figure 3. Score Distribution of the Structure and Written Expression Section

Grade A ranges between scores > 53.559, grade B ranges between scores 48.523 52.999, grade $\mathrm{C}$ ranges between scores 43.447 - 47.999, grade D ranges between scores 33.295 - 42.999, grade E ranges between scores 28.219 - 32.999, grade F ranges between scores $23.143-27.999$. 


\section{Discussion}

The score distribution of Listening Section of the institutional TOEFL of FBS-UWP (IEP) are: A: > 61 ; B: $56-60$; C: $50-55$; D: $39-49$; E: $33-38$; F: $28-32$. Based on the distribution of the listening scores, it is found out that; 1 ) There are no students $(0 \%)$ who belongs to grade A, 2) There is 1 student $(2.85 \%)$ who includes in grade $\mathrm{B}, 3)$ There are 4 students in the class $(11.42 \%)$ gets grade $\mathrm{C}, 4)$ There are 26 students in the class $(74.28 \%)$ belong to grade $\mathrm{D}, 5)$ There are 2 students $(5.71 \%$ ) belongs to grade E, 6) There are 2 students $(5.71 \%)$ of the class belong to grade F. The results of the study showed that there were $74.28 \%$ of the students belong to grade D. It means that the listening section can be the most difficult section of TOEFL for all participants. It was because of some reasons such as fast conversations, unclear voice, and pronunciation, unfamiliar word meanings as well as limited time to do the test.

The score distribution of reading section of the institutional TOEFL of FBS-UWP (IEP) are: A: > 68 ; B: $62-67$; C: $56-61$; D: $45-55$; E: $39-44$; F: 33 - 38. Based on the distribution of the reading scores, it is found out that; 1$)$ There is no student $(0 \%)$ who get grade $\mathrm{A}, 2)$ There is 1 student $(2.85 \%)$ of the class belongs to grade $\mathrm{B}, 3$ ) There are 5 students $(14.28 \%)$ of the class belongs to grade C, 4) There are 20 students $(57.14 \%)$ of the class belongs to grade D, 5) There are 9 students $(25.71 \%)$ of the class belongs to grade E, 6) There is no student $(0 \%)$ gets grade $\mathrm{F}$. The highest average score of TOEFL was the reading section. In this section, the students must comprehend and understand the text as well as get closed meaning to new words and phrases. The results of the study showed that the average score was 50. It means that the reading section can be the easiest section of TOEFL for all participants.

The score distribution of Structure and Written Expression Section of the institutional TOEFL of FBS-UWP (IEP) are: A: > 54 ; B: $49-53$; C: $44-48$; D: 34 - 43 ; E: 29 - 33 ; F: $24-28$. Based on the distribution of the Structure and written scores, it is found out that; 1) There are 2 students (5.71\%) who gets grade A, 2) There is no student (0\%) who gets grade B, 3) There are 6 of the students $(17.14 \%)$ belong to grade C, 4) There are 20 of the students $(57.14 \%)$ belong to grade $\mathrm{D}, 5)$ There are 5 students $(14.28 \%$ ) belong to grade $\mathrm{E}, 6)$ There are 2 of the students $(5.71 \%)$ belong to grade F. The lowest average score of TOEFL was the structure and written expressions section. In this section, the students must know the correct patterns of sentences. The results showed that the average score was 38.71. The students must prepare themselves much better to finish the test. It was because they can not remember all the correct patterns in English sentences. They feel difficulty in correcting the error identification.

\section{CONCLUSION}

The researchers conduct this study with the intention of finding out the holistic description of the achievement of the final-semester students in institutional TOEFL held by the Fakultas Bahasa dan Sastra, Universitas Wijaya Putra Surabaya.

The research bears significant informant for all parties involving in running the academic activities, among others: 1) students are able to know their position among their peers, so they can decide their pace of learning to reach the expected achievement, 2) lectures may know how far their material is grasped, which material still needs remedy and have to be highlighted for the coming semester, 3 ) it is as a means of quality control for the board of the faculty (FBS particularly). 
Since the standard score of institutional TOEFL is 480, which is still high for the students of FBS Universitas Wijaya Putra to obtain, it is necessary to give them good preparation. Suggestion written in this section is not meant to any correction, yet it is expected to share the shoulders among the team. Time allocation should be reconsidered between the training of TOEFL preparation weeks and the execution of the test itself. It is expected that the students have valuable time to prepare themselves well before doing the test. More tactful strategies to help the students' interest and memory stay inflame during the recess time of the training and the administering of the test. Hopefully, they can feel relax and stay calm as well as confident in finishing TOEFL. More alternative modules may be helpful during recess time. They can be an alternative solution to encourage the students to get a high score in TOEFL. The students can study various types of TOEFL items if they want to pass the standard score and have good English proficiency.

\section{ACKNOWLEDGEMENT}

The researchers delivered their thanks to FBS students who participated in this study. The researchers also expressed their gratitude to Universitas Wijaya Putra Surabaya for supporting this research.

\section{REFERENCES}

Ary, D., Jacobs, L. C., \& Razavieh, A. (1972). Introduction to Research in Education. New York: Holt, Rinehart, and Winston.

Brown, D. H. (2004). Language Assessment, Principles, and Classroom Practice. New York, Pearson Education.

Djiwandono, S. (2008). Test Bahasa: Pegangan bagi Pengajar Bahasa. PT. Indeks, Jakarta.

Gay, L. (1987). Educational Research: Competence for Analysis and Application. Columbus: Merrillpub, Co.

Rivers, W. M. (1985). Speaking in Many Tongues: Essays in Foreign-Language Teaching. Cambridge, UK: Cambridge University Press.

Shohamy, E. (1985). A Practical Handbook in Language Testing for the Second Language Teacher. Tel Aviv University Press.

Underhill, N. (1987). Testing Spoken Language: A Handbook of Oral Testing Techniques. New York: Cambridge, University Press. 